\title{
Population structure of the gomphothere Stegomastodon waringi (Mammalia: Proboscidea: Gomphotheriidae) from the Pleistocene of Brazil
}

\author{
DIMILA MOTHÉ ${ }^{1}$, LEONARDO S. AVILLA ${ }^{1}$ and GISELE R. WINCK ${ }^{2}$ \\ ${ }^{1}$ Laboratório de Mastozoologia, Departamento de Zoologia, Universidade Federal do Estado do Rio de Janeiro, \\ Av. Pasteur, 458, sala 501, 14040-901 Rio de Janeiro, RJ, Brasil \\ ${ }^{2}$ Programa de Pós-Graduação em Ecologia e Evolução, Laboratório de Ecologia de Vertebrados, Departamento de Ecologia, \\ Universidade do Estado do Rio de Janeiro, Rua São Francisco Xavier, 524, 20550-019 Rio de Janeiro, RJ, Brasil
}

Manuscript received on October 16, 2009; accepted for publication on May 12, 2010

\begin{abstract}
The Quaternary fossil record of Águas de Araxá (QAA) is represented mainly by an accumulation of skeletal elements of several sizes, which are assigned to a population of Stegomastodon waringi. We analyzed 97 molars according to the wear stages of Simpson and Paula-Couto (1957), and developed a morphometric wear index. The population structure (proportion of immature, subadult, adult, mature adult and senile adult individuals) was identified, and these five age classes were compared to those of extant elephant populations and defined with social implications. The analysis made possible to establish that the population is largely composed of adults: $14.89 \%$ are immature individuals, $23.04 \%$ subadults, $27.65 \%$ adults, $17.21 \%$ mature adults and another $17.21 \%$ senile adults. Based on population structure, we do not discard the possibility that the fossil population was stable or in recovery, and/or was experiencing a high-predation period on younger individuals. The number of individuals composing the past population studied here could suggest that the occupied environment was open due to comparisons to populations of extant elephants. We consider this population as an aggregation of family units, which suggests a time of low environmental humidity. Based on literature and our findings, their extinction appears to be regional and probably related to a catastrophic event.
\end{abstract}

Key words: Stegomastodon waringi, age classes, morphometric wear index, populational structure.

\section{INTRODUCTION}

The Great American Biotic Interchange (GABI) is one of the most important evolutionary events in South American mammalian history. Most of the South American mammalian extant fauna (more than $60 \%$ ) had their origin in North America. However, some of the northern immigrants also became extinct at the end of Pleistocene. One of these groups is the Proboscidea of the family Gomphotheriidae, commonly known as mastodons. They were represented during the Pleistocene in South America by two genera, Cuvieronius and Stegomastodon. In Brazil, the only recognized species

Correspondence to: Leonardo Santos Avilla E-mail: mastozoologiaunirio@yahoo.com.br for the latter genus is $S$. waringi. Together with the giant sloth Eremotherium laurilardii, these are some of the most common Late Pleistocene representatives of megafauna in Brazil (Simpson and Paula-Couto 1957, Alberdi et al. 2002).

Like its closest relatives of Elephantidae (e.g., extant elephants and mammoth), mastodons are characterized by a brachicephalic and brevirrostrine skull and a quite short jaw symphysis (Osborn 1921, Paula-Couto 1979, Prado et al. 2001, Prado and Alberdi 2008). Haynes (1991) suggests that extinct taxa, as Mammut, Mammuthus and mastodons, may not have lived in the same habitats, but they presented the same behavior and their life histories could be similar to the ones of extant proboscideans. Nevertheless, the most charac- 
teristic difference between Pleistocene mastodons and Elephantidae is that the latter displays bunodont molars, which is considered a proboscidean plesiomorphic feature.

The proboscidean dentition is highly specialized and consists of a pair of tusks (incisors) and six cheek teeth in each half of the jaw. Furthermore, the mastodon $S$. waringi bears bunolophodont, trilophodont or polilophodont molars with relatively low crowns (PaulaCouto 1979). The $S$. waringi dental formula is I $1 / 0$, C 0/0, M 6/6, like extant elephants, although only the fourth $\left(\mathrm{M}_{1}^{1}\right)$, fifth $\left(\mathrm{M}_{2}^{2}\right)$, and sixth $\left(\mathrm{M}_{3}^{3}\right)$ molariform teeth are considered true molars (Simpson and Paula-Couto 1957, Paula-Couto 1979). The deciduous dentition is formed by the first three molars, the first tooth being bilophodont, while the second and the third ones are trilophodont. Each subsequent molar tends to be larger and to have a more complex crown surface than the previous tooth (Mothé and Avilla 2008). As they wear down, they display depressions in a clover-like format (Paula-Couto 1979, Prado et al. 2001, Alberdi et al. 2007, Mothé and Avilla 2008).

Asher and Lehmann (2008) suggest that many similarities are shared by Afrotherian mammals (Proboscidea, Sirenia, Hyracoidea, Tubulidentata, Macroscelididae, Tenrecidae and Chrysochloridae) mainly concerning the pattern of dental ontogeny and replacement. Especially in proboscideans, molar eruption occurs in the horizontal direction, from the rear to the front of the jaw. In general, only a single tooth or one tooth plus a part of another one are in use in each half jaw at the same time. The molar becomes severely worn during the period of usage and, as a new molar is formed, it gradually moves forward and replaces the worn tooth in use (Johnson and Buss 1965, Peyer 1968, Aguirre 1969, Maglio 1972, Shoshani 1998, Vaughan et al. 2000, Prothero and Schoch 2002).

The Águas de Araxá Pleistocene fossiliferous assemblage is unique in several aspects: no other South American Pleistocene deposit presents a concentration of numerous dental and skeletal fragments in various sizes representing different bones of gomphotheres. Although other mammals were recorded (e.g., equids, macrauchenids, megatheriids), the largest number of identifiable elements was unquestionably from $S$. waringi. The uniqueness of this deposit drew the atten- tion of Simpson and Paula-Couto (1957), who recognized the mastodon assemblage from Araxá as a single population. Thus, based on the proboscidean horizontal tooth replacement, we conducted a dental wear-based study of this population and recognized six tooth wear classes. Wear-lacking teeth and completely worn ones were considered as representing extremity classes. However, the authors used subjective criteria to define intermediate classes (Simpson and Paula-Couto 1957, Table I). Therefore, we reviewed here the wear-based classes proposed by Simpson and Paula-Couto (1957), inferring an age-sequence in order to recognize the population structure of Stegomastodon waringi from the Pleistocene of Águas de Araxá.

\section{STUDY AREA AND GEOLOGY}

The Araxá mastodons were discovered during the development of the mineral springs at Águas de Araxá $\left(19^{\circ} 25^{\prime} 53^{\prime \prime} 19^{\circ} 50^{\prime} 09^{\prime \prime} \mathrm{S}\right.$ and $\left.46^{\circ} 44^{\prime} 27^{\prime \prime} 47^{\circ} 13^{\prime} 38^{\prime \prime} \mathrm{W}\right)$, a few kilometers away from the municipality of Araxá (Fig. 1).

The $S$. waringi fossils were found in a pothole, in a deposition area of a Pleistocene stream. After its original formation, the pothole was filled with sediments and fossils, and two layers formed. The material from the deeper deposits was poorly sorted and included most of the bones and also rounded boulders up to $30 \mathrm{~cm}$. Towards the top, sorting became greater and the sediments finer, and the bones from this part were more fragmentary and water-worn. The upper layer sediments, with well-rounded pebbles and many worn bone fragments, were later cemented by iron oxide, forming a hard covering that preserved the deposit. The coarse lower part of the pothole filling, with the well-preserved bones and teeth, was probably deposited by fast-flowing water, with rapid filling. The most probable interpretation is that the bones washed into the pothole by freshets represented animals that were contemporaneous (Price 1944, Simpson and Paula-Couto 1957).

\section{MATERIALS AND METHODS}

The dental specimens evaluated here with the morphometric wear index are housed at the mammalian fossil collection of the Departamento Nacional de Produção Mineral, Rio de Janeiro, Brazil (specimen's sample code: 
TABLE I

Molariform teeth wear stages established by Simpson and Paula-Couto, 1957. Intermediate stages correspond to the numbers 1,2 and 3.

\begin{tabular}{c|c}
\hline Wear stage & Wear description \\
\hline 0 & Tooth formed but not erupted \\
\hline $0+$ & Tooth erupted but not worn \\
\hline 1 & Wear present only in anterior lophids \\
\hline 2 & Light wear in all lophids \\
\hline 3 & Great wear with lophids still visible \\
\hline 4 & Severe wear with lophids partially or totally obliterated \\
\hline
\end{tabular}

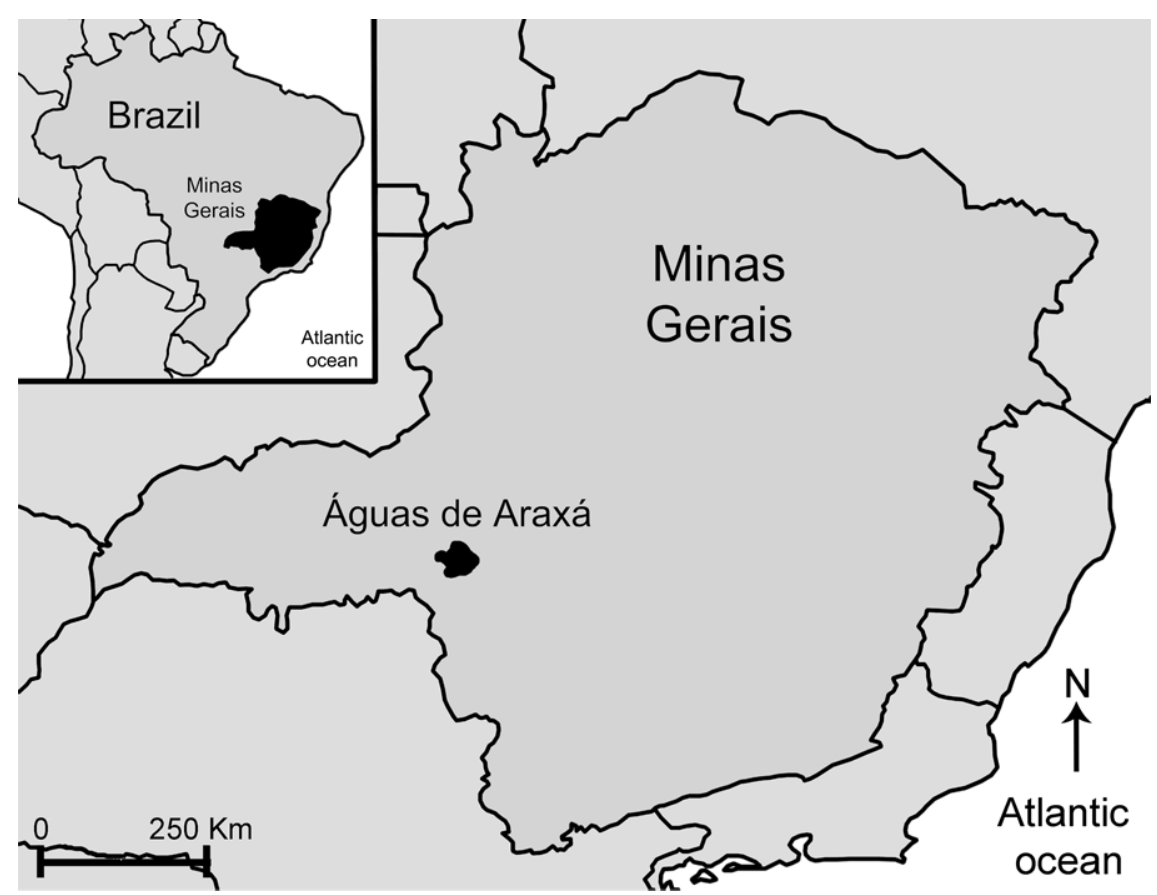

Fig. 1 - Location of Minas Gerais State. Águas de Araxá locality is represented on the largest map by the darkened area.

DGM). However, six specimens are housed at the American Museum of Natural History (AMNH, New York, USA), two specimens in situ at Águas de Araxá, Minas Gerais, Brazil, and one at the collection of the University of Minas Gerais, current Universidade Federal de Minas Gerais (specimen's sample code: UMG Ib-15,). Altogether, we analyzed 97 molars, both isolated and in situ, of which 49 specimens are lower molars and 48 upper molars.

Except for the specimens from the AMNH and the ones in situ at Araxá - that were analyzed based on the wear stages proposed by Simpson and Paula-Couto 1957 - we measured in each molar (in millimeters) the greatest height of the crown in the labial and lingual faces at the metaloph(id) and tritoloph(id), as well as the greatest width of the depression resulting from wear in each loph(id), i.e., the area with exposed dentine (Fig. 2). On the proboscideans wear pattern, lingual cusps become worn faster than labial cusps on upper teeth, while on lower teeth the labial cusps become worn faster than lingual cusps (Maglio 1972). Thus, the average between the cusps measurements (crown height 
and width of area with exposed dentine in each cusp) demands to establish a balance among the differences caused by the teeth wear.

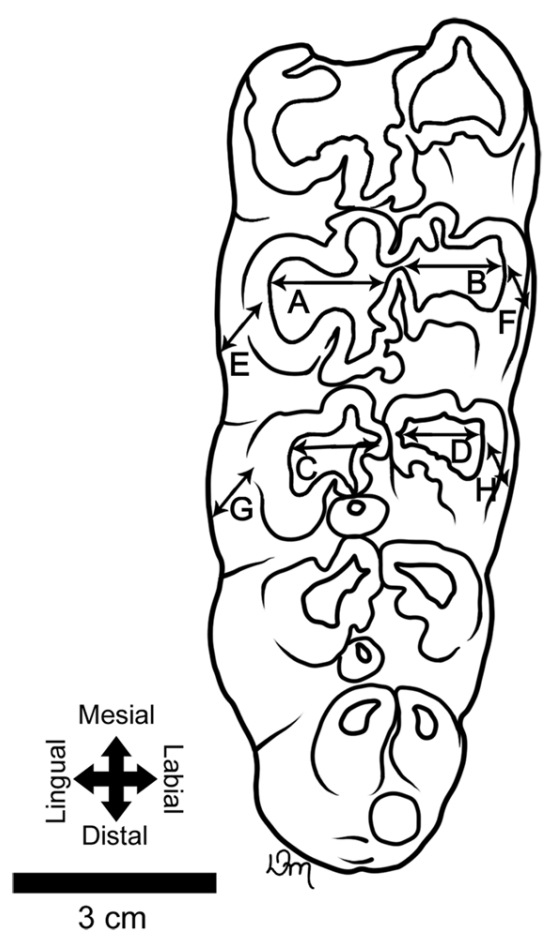

Fig. 2 - Diagram of a left $\mathrm{M}_{3}$ tooth of Stegomastodon waringi with the measured regions (Oclusal view). A) Greater width of lingual metalophid cusp depression. B) Greater width of labial metalophid cusp depression. C) Greater width of lingual tritolophid cusp depression. D) Greater width of labial tritolophid cusp depression. E) Greater height of lingual metalophid cusp. F) Greater height of labial metalophid cusp. G) Greater height of lingual tritolophid cusp. H) Greater height of labial tritolophid cusp.

We developed a morphometric wear index relating the average of the ratios between the height of the metaloph(id) and tritoloph(id) cusps to the depression width of each one (cusp height/depression width). Subsequently, we built scatterplots for each molar type, in which the metaloph(id) morphometric indexes are plotted in the $\mathrm{Y}$ axis and the tritoloph(id) indexes in the $\mathrm{X}$ axis. The fragmented specimens, which are the molars from the AMNH and the in situ ones, and teeth representing the extremities of wear classes in Simpson and Paula-Couto (1957) (i.e., when depressions in unworn teeth were absent, and when there was no cusp definition in completely worn teeth) were not included in the morphometric analysis. However, we could infer a wear stage and an age group for these molars, through pictures on the study of Simpson and Paula-Couto (1957).

Extant elephant tooth-based age definition studies formed the basis for the recognition of age classes in the $S$. waringi population from Águas de Araxá (Perry 1953, Laws 1966, Krumrey and Buss 1968, Laursen and Bekoff 1978, Roth and Shoshani 1988, Froehlich and Kalb 1995, Moss 1996). Therefore, the population structure (the proportion of immature, subadult, adult, mature adult and senile adult individuals) was identified and compared to extant elephant populations.

To infer ages for the mastodons from Águas de Araxá, we used the teeth usage intervals suggested by Moss (1996) because they include the main use periods that were proposed and do not suggest dubious intervals of use, compared to other studies (Laws 1966, Laursen and Bekoff 1978, Roth and Shoshani 1988, Froehlich and Kalb 1995). For example, Laursen and Bekoff (1978) suggest the second molar without a sole period of use in the jaw or mandible. On the other hand, Moss (1996) suggests the eruption of the Dp2/DP2, Dp3/DP3 and Dp4/DP4 happens at about zero, six months and one year of age, and their loss at about one, seven and eleven years, respectively, while the first, second and third permanent molars appear in the mouth about ten, fourteen and twenty eight years, and their loss happens at about twenty two, forty years and in the end of life, respectively. Therefore, the age groups used to the molar classification of the mastodons from Águas de Araxá were based on the intervals of use also proposed by this author.

Even if we had applied other use intervals, as suggested by Roth and Shoshani (1988), the molars corresponding age would be close or equal to those here established. It can be explained by the proposed ages are being always in the nearest age group, although they diverge on the exactly same age for eruption and loss of each molar. Through the comparison to extant elephant populations, we used the age classes proposed by Haynes (1991): immature (0-12 years old), subadult (1324 years), adult (25-36 years), mature adult ( $37-48$ years) and senile adult (49-60 years).

Concerning the age classes here recognized, the immature individuals are those with no reproductive development; subadults those that could biologically reproduce but were not yet doing so; adults the reproduc- 
tively active animals; and the mature adults those with less reproductive activity. The latter class includes individuals that are past their prime in reproductive activity, as seen with extant elephants from the age of about 50 years and on (Haynes 1991, Owen-Smith 2000). Moreover, in this group are placed the socially well-positioned individuals, i.e., the dominant males and the matriarchs of the herd. Therefore, our classes are defined with social, behavioral and biological implications.

The individuals counting was done following the MNI index (minimum number of individuals), in which the number of individuals of an assemblage is determined based upon counts of the most abundant element present in one side of the body, like right mandible, or upon counts determined by joint consideration of the skeletal parts represented by: size, age and wear stage (Badgley 1986, Marshall and Pilgram 1993).

\section{RESULTS}

We observed that the more the molar is worn, the lower is its height and the greater is the width of the depression in each loph(id). Based on the results of scatterplots, the molars are distributed according to the morphometric index values: teeth with the highest values are plotted far from zero in the $\mathrm{X}$ and $\mathrm{Y}$ axes, and correspond to the less worn molars. On the other hand, teeth with lower values are placed closer to zero in both axes, and are the molars with more wear. Teeth from the intermediate classes are distributed in a gradient of morphologic index values, showing different degrees of wear.

Only one specimen of Dp3 was recognized, and it was totally worn (DGM 67M, Fig. 3A). Only one specimen of Dp4 was found, and it was not worn (DGM 752M, Fig. 3B). Every specimen of DP4 was in the intermediate classes (Fig. 3C, right tooth), i.e. there are not DP4 specimens without wear or totally worn. Three first molar (M1 and m1) specimens showed dental crown without wear and were included in the no-wear class. In the intermediate classes, 10 first molars showed the metaloph(id) more worn than the tritoloph(id) (Fig. 3C, left tooth, and D), and two first molar specimens were in the total wear stage. Considering the second molars (M2 and $\mathrm{m} 2$ ), five specimens were observed with no wear, and 22 were located in the intermediate classes (Fig. 3E and F). Three lower second molars have a completely obliterated crown and were placed in the total wear class. There is no specimen of second upper molar with total wear. Six specimens of third molar (M3 and m3) presented no wear on the cusps. In the intermediate classes, 23 teeth were found (Fig. 3G and $\mathrm{H}$ ). Two teeth showed unusual wear (DGM 138M and DGM 60M B), i.e., the indexes values were very contradictory among themselves. Five specimens of third molar were in total wear.

Thus, among the 97 analyzed specimens, the minimum number of individuals found is 47 . To find this number, the specimens were grouped according to the type of molar, the similar position in the mouth (if the tooth is left or right and upper or lower) and the wear stage (Figs. 4 and 5).

Considering the age classes identified here (see Fig. 6), we suggest that the Quaternary mastodon population from Águas de Araxá is composed of 14.89\% immature individuals (0-12 years), 23.04\% subadults (13-24 years), $27.65 \%$ adults (25-36 years), and has an equal number of mature adults (37-48 years) and senile adults (49-60 years or more): $17.21 \%$. We draw attention to the elevated percentage of older adults (above 37 years old), which indicates a high longevity rate recorded for this population (Fig. 6).

\section{DISCUSSION}

The molars with complete crowns present little or no wear, while the teeth with an obliterated crown show wear in some level. As seen before in the graphs, as distance increases from both axes, the tooth is less worn. Consequently, the molars with the greatest wear are near to the axis origin, with low index values. Since the crown wear increases with tooth usage, when comparing two molars of the same type, the oldest individual molar will be the one with the most worn cusps. Thus, the molars farther from the zeros are related to the younger individuals within the group.

Several studies of extant proboscideans (Loxodonta africana and Elephas maximus) use dental wear for age determination, as well as correlation of body dimensions (Perry 1953, Johnson and Buss 1965, Laws 1966, Krumrey and Buss 1968, Laursen and Bekoff 1978, Roth and Shoshani 1988, Froehlich and Kalb 1995). However, there are differences in the proposed time intervals of 

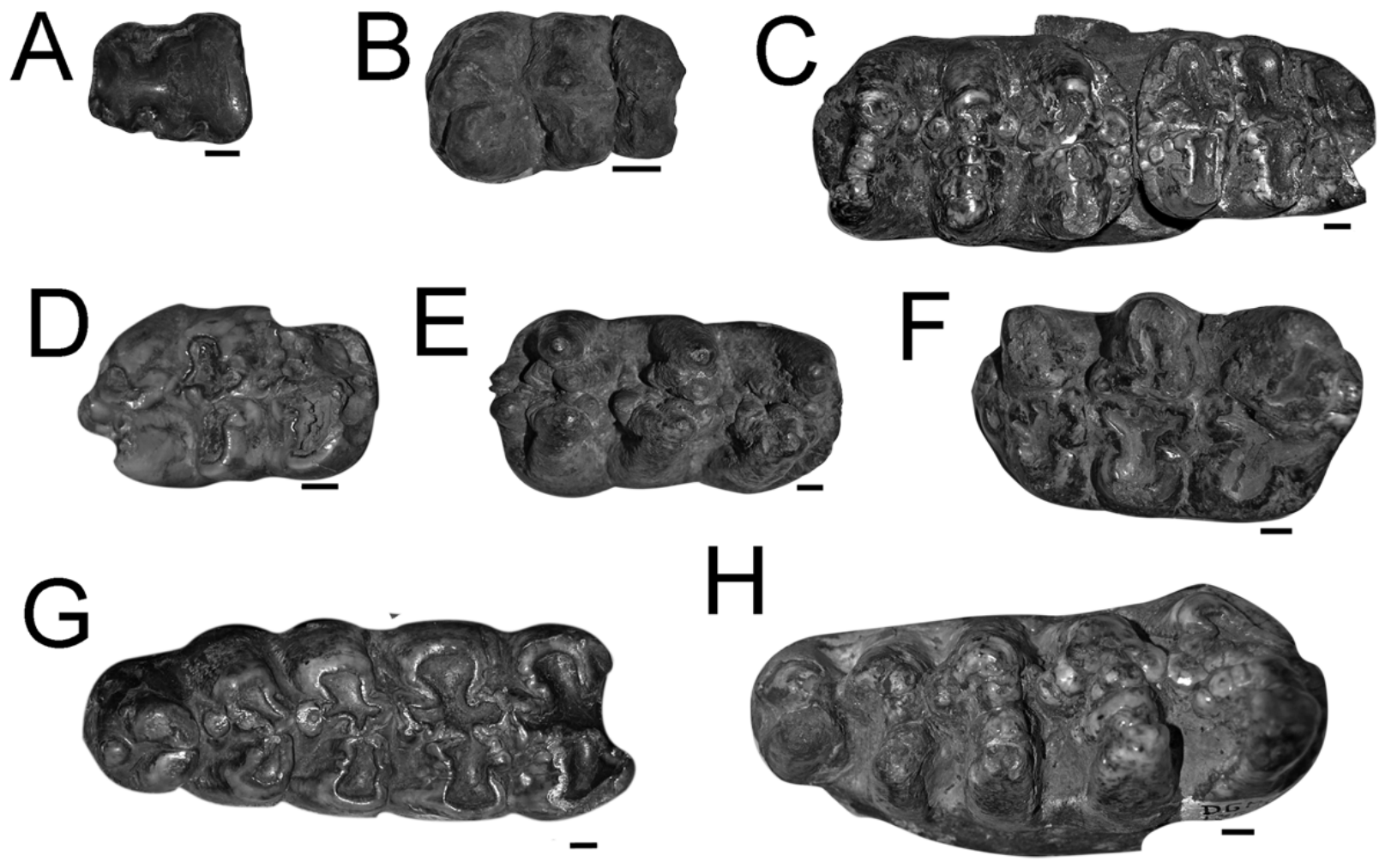

Fig. 3 - Molars of Stegomastodon waringi from the Quaternary of Águas de Araxá. A) Dp3: lower right molar in total wear (DGM 67M); B) Dp4: upper left molar without wear (DGM 752M); C) DP4 and M1: Upper right molars in wear stages 2 and 1 (DP4 at right and M1 at left, DGM 73M); D) m1: Lower left molar in wear stage 2 (DGM 141M); E) m2: Lower right molar without wear (DGM 75M); F) M2: Upper right molar in wear stage 2 (DGM 104M); G) m3: Lower left molar in wear stage 3 (DGM 133M); H) M3: Lower left molar in wear stage 2 (DGM 135M).

molar use according to each author. For instance, Laws (1966) argued that the first molar is lost at about 28 years of age, the second one at about 43 , and the third one erupts at about 30. Meanwhile, Laursen and Bekoff (1978) assert that the first molar erupts at about five years of age and remains in use until 25, the second molar appears at about 13 and ends its period of usage at around 35, and the third molar erupts at about 25 and persists until the death of the animal.

The mastodon population of QAA has a profile similar to a declining population (Fig. 5C), if we compare the percentage of immature and adults. The percentage of subadults of the gomphothere population is similar to the one of an expanding population, but the great presence of mature and senile adults $(34.42 \%)$ is peculiar to a declining population of extant African elephants (Haynes 1991, McNeil et al. 2004, Hildebrandt et al. 2007, and literature therein). Some authors state that expanding mammal populations have a preponderance of young individuals, while declining populations are mainly comprised of mature to old individuals (Haynes 1991, McNeil et al. 2004). This would be especially reported on larger mammals, with long periods of gestation and parental care, e.g., extant elephants, and gestations of 18 to 22 months (Perry 1953, Sukumar 2003 apud Hildebrandt et al. 2007). However, OwenSmith (2000) presents dissimilar data on several elephant populations from different localities in Africa. The author relates the proportion of adults ( $>15$ years) ranging between $34-38 \%$ in the increasing population of Kruger National Park (South Africa); and over 50\% for populations putatively stable (Luangwa in Zambia), or recovering from large-scale drought mortality (Tsavo East National Park in Kenya, in 1974). Moreover, population densities and classes' age size can be a consequence of the interaction of several factors, such as 

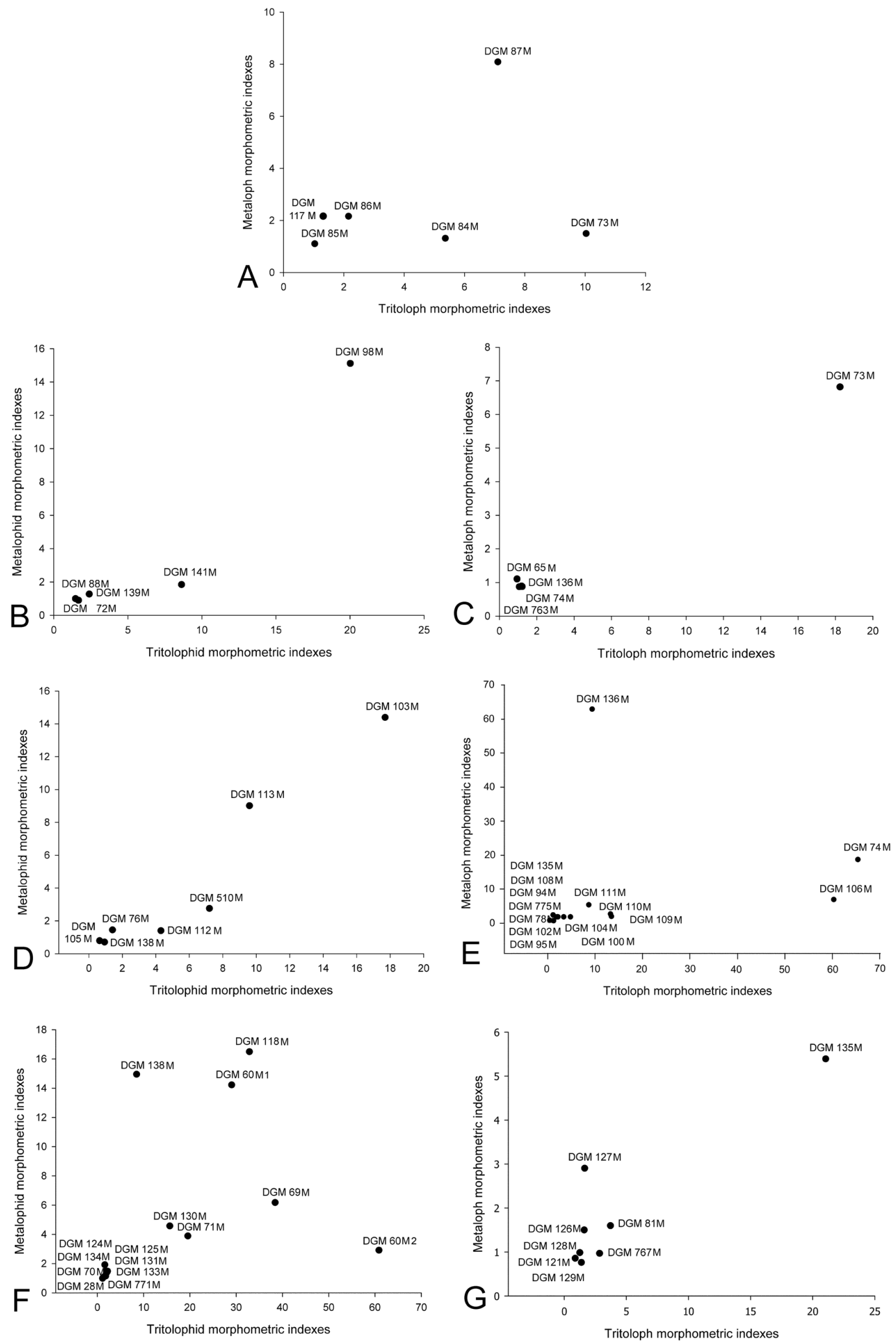

Fig. 4 - Molars wear according to the indexes of wear measured on metaloph (id) and tritoloph (id) of the mastodons from the QAA. A) The upper deciduous molar scatterplot. B) The lower first molar. C) The upper first molars. D) The lower second molars. E) The upper second molars. F) The lower third molars. G) The upper third molars. 


\begin{tabular}{|c|c|c|c|c|c|c|}
\hline \multirow{2}{*}{ Type of molar } & \multirow{2}{*}{ Specimen } & \multirow{2}{*}{ Side - } & \multicolumn{2}{|c|}{ Morphometric wear index values } & \multirow{2}{*}{ Wear stage } & \multirow{2}{*}{ Age (years) } \\
\hline & & & Metaloph(id) & Tritoloph(id) & & \\
\hline Dp3 & DGM 67M & Right & \multicolumn{2}{|c|}{ Total wear } & 4 & 7 \\
\hline Dp4 & DGM 752M & Left & \multicolumn{2}{|c|}{ No wear } & 0 & 1 to 3 \\
\hline \multirow{6}{*}{ DP4 } & DGM 73M & Right & 1.5 & 10.03 & 2 & 3 to 5 \\
\hline & DGM 84M & Left & 1.32 & 5.36 & 3 & 5 to 7 \\
\hline & DGM 85M & Right & 1.11 & 1.03 & 3 & 7 to 9 \\
\hline & DGM 86M & Right & 2.16 & 2.15 & 3 & 5 to 7 \\
\hline & DGM 87M & Right & 8.09 & 7.11 & 2 & 3 to 5 \\
\hline & DGM 117M & Right & 2.19 & 1.36 & 3 & 7 to 9 \\
\hline \multirow{8}{*}{$\mathrm{m} 1$} & DGM 762M & Right & \multicolumn{2}{|c|}{ No wear } & 0 & 10 to 12.5 \\
\hline & DGM 72M & Right & 0.9 & 1.67 & 3 & 17.5 to 20 \\
\hline & DGM 139M & Right & 1.28 & 2.39 & 3 & 17.5 to 20 \\
\hline & DGM 141M & Left & 1.85 & 8.62 & 2 & 15 to 17.5 \\
\hline & DGM 88M & Left & 0.99 & 1.47 & 3 & 17.5 to 20 \\
\hline & DGM 98M & Right & 15.12 & 20.02 & 1 & 12.5 to 15 \\
\hline & DGM 755M & Left & \multicolumn{2}{|c|}{ Fragmented } & & \\
\hline & DGM 758M & Left & \multicolumn{2}{|c|}{ Total wear } & 4 & 20 to 22 \\
\hline \multirow{10}{*}{ M1 } & DGM 73M & Right & 6.82 & 18.24 & 1 & \\
\hline & DGM 136M & Left & 0.88 & 1.21 & 3 & 12.5 to 15 \\
\hline & DGM 64M & Left & \multicolumn{2}{|c|}{ Total wear } & 4 & 20 to 22 \\
\hline & DGM 65M & Right & 1.11 & 0.94 & 3 & 12.5 to 15 \\
\hline & DGM 93M & Right & \multirow{2}{*}{\multicolumn{2}{|c|}{$\begin{array}{l}\text { No wear } \\
\text { Fragmented }\end{array}$}} & 0 & 10 to 12,5 \\
\hline & DGM 751M & Right & & & & \\
\hline & DGM 763M & Right & 0.87 & 1.06 & 3 & 12.5 to 15 \\
\hline & DGM 776M & Left & Frag & ted & & \\
\hline & DGM 74M & Left & 0.89 & 1,19 & 3 & 12.5 to 15 \\
\hline & AMNH 45981 & Right & No & & 3 & 12.5 to 15 \\
\hline & DGM 75M & Right & & & 0 & 14 to 19 \\
\hline & DGM 101M & Left & Tot & & 4 & 35 to 40 \\
\hline & DGM 759M & Right & Tot & & 4 & 35 to 40 \\
\hline & DGM 70M & Left & Tot & & 4 & 35 to 40 \\
\hline & DGM 97M & Left & Frag & ted & & \\
\hline & DGM 112M & Left & 1.41 & 4.31 & 3 & 19 to 24 \\
\hline & DGM 113M & Left & 9.02 & 9.59 & 2 & 24 to 29 \\
\hline $\mathrm{m} 2$ & DGM 138M & Left & 0.71 & 0.94 & 3 & 34 to 41 \\
\hline & DGM 76M & Left & 1.45 & 1.41 & 3 & 19 to 24 \\
\hline & DGM 510M & Right & 2.77 & 7.19 & 3 & 24 to 29 \\
\hline & DGM 103M & Right & 14.39 & 17.6 & 2 & 24 to 29 \\
\hline & DGM 105M & Left & 0.79 & 0.64 & 3 & 34 to 41 \\
\hline & AMNH 45977 & Left & No & & 1 & 19 to 24 \\
\hline & AMNH 45978 & Right & No & & 3 & 19 to 24 \\
\hline & DGM 94M & Left & 1.95 & 2.39 & 3 & 29.6 to 35 \\
\hline & DGM 95M & Left & 0.89 & 0.71 & 3 & 29.6 to 35 \\
\hline & DGM 96M & Left & Frag & ited & & \\
\hline & DGM 100M & Left & 1.83 & 5.01 & 3 & 29.6 to 35 \\
\hline & DGM 102M & Left & 0.9 & 1.34 & 3 & 29.6 to 35 \\
\hline & DGM 109M & Left & 2.01 & 13.49 & 2 & 24 to 29 \\
\hline & DGM 110M & Right & 2.53 & 1332 & 2 & 24 to 29 \\
\hline & DGM 135M & Left & 0.75 & 0.85 & 3 & 29,6 to 35 \\
\hline 12 & DGM 775M & Right & 1.82 & 2.21 & 3 & 29,6 to 35 \\
\hline IM12 & DGM 104M & Right & 1.69 & 3.62 & 2 & 29,6 to 35 \\
\hline & DGM106M & Right & 6.81 & 60.46 & 2 & 19 to 24 \\
\hline & DGM 111M & Right & 5.32 & 8.74 & 2 & 24 to 29 \\
\hline & DGM 136M & Left & 62.93 & 9.49 & 2 & 19 to 24 \\
\hline & DGM 89M & Left & & & 0 & 14 to 19 \\
\hline & DGM 74M & Left & 18.69 & 65.46 & 2 & 19 to 24 \\
\hline & AMNH 45980 & Right & No & & 0 & 14 to 19 \\
\hline & DGM 78M & Left & 1.45 & 1.59 & 3 & 29.6 to 35 \\
\hline & DGM 108M & Right & 2.05 & 1.28 & 3 & 29.6 to 35 \\
\hline
\end{tabular}

Fig. 5 - Intermediate group of dentary specimens assigned by Simpson and Paula-Couto (1957) and reviewed here by our proposed morphometric index. The specimens with "No access" correspond to those in situ and those housed at the American Museum of Natural History (New York, USA), in situ and at the Universidade Federal de Minas Gerais (Minas Gerais, Brasil). 


\begin{tabular}{|c|c|c|c|c|c|c|}
\hline \multirow[b]{2}{*}{ Type of molar } & \multirow[b]{2}{*}{ Specimen } & \multirow[b]{2}{*}{ Side } & \multicolumn{2}{|c|}{ Morphometric wear index values } & \multirow{2}{*}{ Wear stage } & \multirow{2}{*}{ Age (years) } \\
\hline & & & Metaloph(id) & Tritoloph(id) & & \\
\hline \multirow{26}{*}{$\mathrm{m} 3$} & DGM 132M & Left & \multicolumn{2}{|c|}{ No wear } & 0 & 28 to 34 \\
\hline & DGM 139M & Right & \multicolumn{2}{|c|}{ No wear } & 0 & 28 to 34 \\
\hline & DGM 60M 1 & Left & 14.23 & 29.02 & 1 & 34 to 41 \\
\hline & DGM 60M 2 & Right & 2.92 & 608.65 & 1 & 34 to 41 \\
\hline & DGM 70M & Left & 1.48 & 2.21 & 3 & 47 to 53 \\
\hline & DGM 71M & Right & 3.89 & 19.55 & 2 & 41 to 47 \\
\hline & DGM 131M & Right & 1.35 & 1.95 & 3 & 47 to 53 \\
\hline & DGM 133M & Left & 1.14 & 1.57 & 3 & 47 to 53 \\
\hline & DGM 134M & Right & 1.12 & 1.49 & 3 & 47 to 53 \\
\hline & DGM 137M & Left & \multicolumn{2}{|c|}{ No wear } & 0 & 28 to 34 \\
\hline & DGM 138M & Left & 14.96 & 8.49 & 1 & 34 to 41 \\
\hline & DGM 28M & Right & 0.99 & 1.12 & 3 & 47 to 53 \\
\hline & DGM 46M & Right & \multicolumn{2}{|c|}{ Fragmented } & & \\
\hline & DGM 69M & Left & 6.18 & 38.42 & 1 & 34 to 41 \\
\hline & DGM 118M & Left & 16.49 & 32.86 & 1 & 34 to 41 \\
\hline & DGM 124M & Right & 1.93 & 1.61 & 3 & 47 to 53 \\
\hline & DGM 125M & Left & 1.49 & 1.95 & 3 & 47 to 53 \\
\hline & DGM 130M & Right & 4.58 & 15.65 & 2 & 41 to 47 \\
\hline & DGM 770M & Right & \multicolumn{2}{|c|}{ Total wear } & 4 & $53+$ \\
\hline & DGM 771M & Right & 1.16 & 1.79 & 3 & 47 to 53 \\
\hline & DGM 760M & Left & \multicolumn{2}{|c|}{ No wear } & 0 & 28 to 34 \\
\hline & DGM 120M & Right & \multicolumn{2}{|c|}{ Total wear } & 4 & $53+$ \\
\hline & DGM 766M & Right & \multicolumn{2}{|c|}{ Fragmented } & & \\
\hline & AMNH 45976 & Right & \multicolumn{2}{|c|}{ No access } & 1 & 34 to 41 \\
\hline & in sit & Right & \multirow{2}{*}{\multicolumn{2}{|c|}{ No access }} & 3 & 47 to 53 \\
\hline & 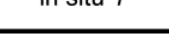 & Left & & & 3 & 47 to 53 \\
\hline \multirow{20}{*}{ M3 } & DGM 116M & Left & \multicolumn{2}{|c|}{ No wear } & 0 & 28 to 34 \\
\hline & DGM 122M & Right & \multicolumn{2}{|c|}{ No wear } & 0 & 28 to 34 \\
\hline & DGM 749M & Left & \multicolumn{2}{|c|}{ Total wear } & 4 & $53+$ \\
\hline & DGM 750M & Right & \multicolumn{2}{|c|}{ Total wear } & 4 & $53+$ \\
\hline & DGM 765M & Left & Frag & nted & & \\
\hline & DGM 772M & Left & Tot & & 4 & $53+$ \\
\hline & DGM 774M & Left & Frag & nted & & \\
\hline & DGM 81M & Right & 3.72 & 1.59 & 3 & 34 to 41 \\
\hline & DGM 117M & Right & Frag & nted & 2 & 47 to 53 \\
\hline & DGM 127M & Left & 1.64 & 2.9 & 3 & 34 to 41 \\
\hline & DGM 121M & Left & 0.88 & 0.86 & 3 & 34 to 41 \\
\hline & DGM 126M & Right & 1.61 & 1.51 & 3 & 34 to 41 \\
\hline & DGM 128M & Left & 1.25 & 0.98 & 3 & 34 to 41 \\
\hline & DGM 129M & Right & 1.38 & 0.76 & 3 & 34 to 41 \\
\hline & DGM 135M & Left & 21.05 & 5.39 & 2 & \\
\hline & DGM 767M & Right & 2.84 & 0.97 & 3 & 34 to 41 \\
\hline & DGM 761M & Left & Frag & nted & & \\
\hline & UMG Ib-15 & Left & No & & 0 & 28 to 34 \\
\hline & AMNH 45979 & Left & No & ess & 0 & 28 to 34 \\
\hline & in situ 2 & Right & No & ess & 2 & 47 to 53 \\
\hline
\end{tabular}

Fig. 5 (continuation).

climate, density and availability of prey, presence/absence of competitors and predators, epidemics and population genetic diversity (see Packer et al. 2005 and Prevosti and Vizcaíno 2006). Therefore, the gomphothere age profile may also be the result of a period of heavy predation on younger individuals. Loveridge et al. (2006) observed that elephant calves are extremely vulnerable to predation by large carnivores, and they are more vulnerable during dry periods, when they may become lost or separated from family groups.
Following data from extant elephant population recorded in Owen-Smith (2000), we cannot discard the possibility that the fossil population was stable or in recovery. In addition, it is possible that the event of gomphothere mass death event corresponds to the beginning of a rainy season. Consequently, it occurred at the beginning of what would have been the reproductive season. This interpretation is in accordance with the ecology and biology of living elephants. Extant African savanna or bush elephants usually associate in a nuclear group 

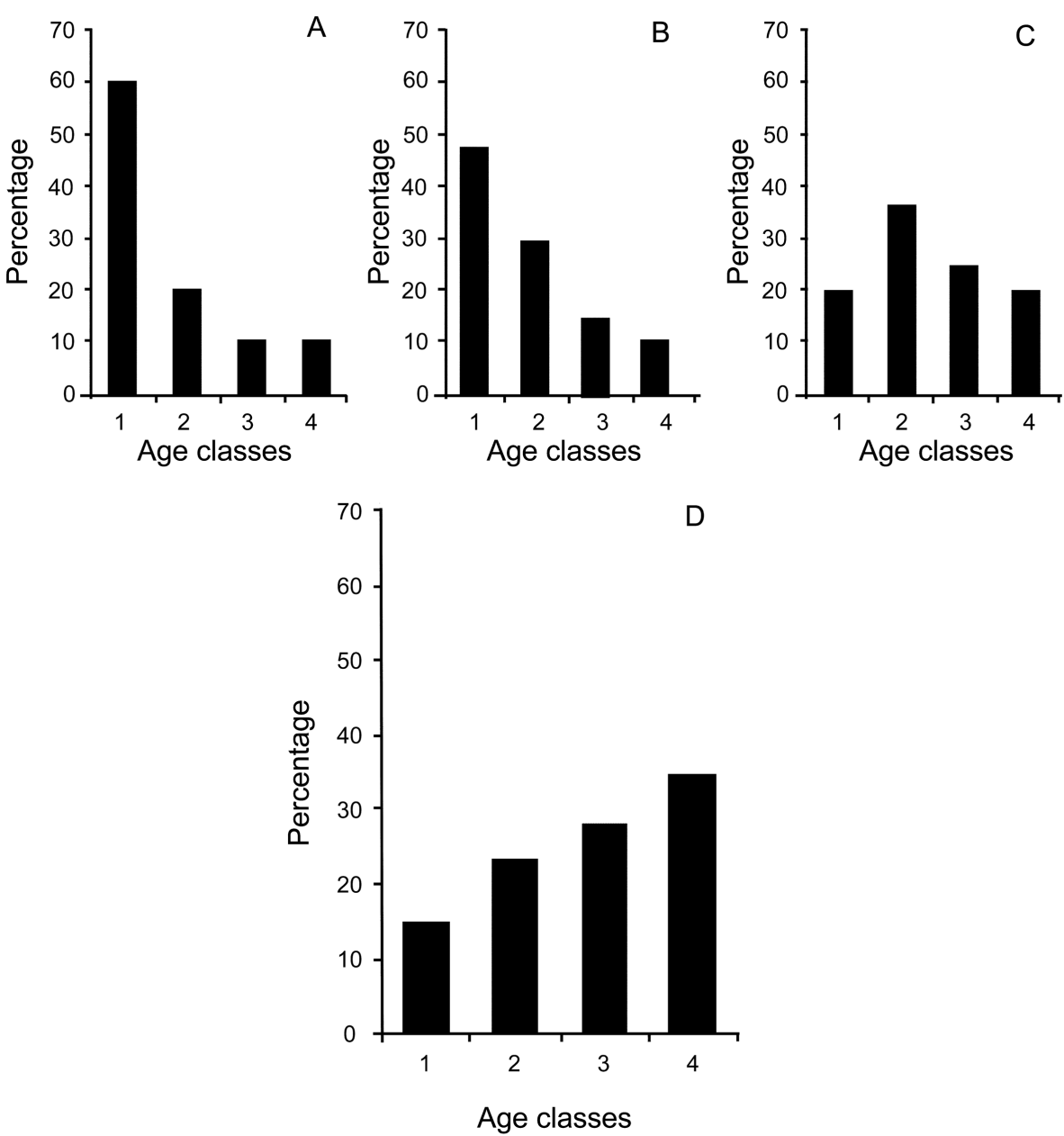

Fig. 6 - Age profiles of populations with different demographic status: A) Expanding; B) Stable; C) Declining (all three modified from Haynes, 1991); D) Profile of the Stegomastodon waringi population from Águas de Araxá, Minas Gerais, Brazil. Age Classes: 1) 0-12 yrs; 2) 13-24 yrs; 3) 25-36 yrs and 4) 37-60 yrs.

(family unit) composed of an adult female with one to three immature offsprings (Owen-Smith 2000), but often two to four females and their youngs are found together in combined family units (from four to 12 animals) (Owen-Smith 2000). Adult males may be solitary, associated in small all-male groups, or attached to female groups. Despite the reduced number of family units, usually they may be found close to each other (less than one kilometer away) and moving synchronously side by side. Additionally, larger aggregations of elephants (100-1300), including males, have been observed during the wet season, holding together for several weeks at a time (Owen-Smith 2000). Throughout the dry sea- son, it is mainly the nuclear or small combined family units that can be found (i.e., some mothers and their youngs). In contrast, forest elephants are generally seen in small groups with a maximum of nine individuals (average of 3.4; Owen-Smith 2000). Therefore, the number of mastodon individuals composing the fossil population in this study may indicate that the occupied environment was an open formation (savannah-like), as suggested by other authors (Sánchez et al. 2004 and citations therein), and we submit that the mastodon population was an aggregation of nuclear family units.

Ledru (1993) and Ledru et al. (1996), through palynological analysis, found in a close region to Águas de 
Araxá (the location of Salitre $-19^{\circ} \mathrm{S} 46^{\circ} 46^{\prime} \mathrm{W}, 980 \mathrm{~m}$ height), a sequence of different environments for the last 60.000 yr B.P. A cold and arid period was registered until 50.000 yr B.P., followed by a gradual increase in the climatic humidity from 45.000 to 33.000 yr B.P. inferred from the increase in semi-deciduous tree taxa and between 17.000 and 13.000 yr B.P. the development of a transitional forest indicates cold and a two-month dry season conditions. At the end of Pleistocene, the climatic conditions became moister and the forest expanded. However, between 11.000 and 10.000 yr B.P., the forest disappeared, suggesting a return to a cold and dry climate. This succession of vegetations is related to rapid climate changes. Nowadays, the natural vegetation refers to Cerrado (Brazilian-savanna) and the climate is characterized by a four-month dry season and mean winter temperatures above $15^{\circ} \mathrm{C}$, although all these different vegetation types persist in small areas of Salitre.

A catastrophic mass death (Holz and Simões 2002) is defined as a great event of death in which there is no age or gender selection of individuals, such as the mortalities caused by long environmental dry periods or resources scarcity. Thus, we propose that the mastodons of the aggregation here described may have died together during a time of low environmental humidity. Loss of water sources caused by dry climatic conditions would have led to density-dependent deaths as a result of crowding around water sources, as well as overcrowding and overgrazing migration routes. In times of drought, proboscideans suffer mass deaths at water refuges (Haynes 1991).

The gomphothere remains of QAA also have a similar taphonomic signature, i.e., they underwent the same taphonomic processes (Dominato et al. 2009). The post mortem history shows a low weathering stage of bones and dental remains (stages 0-1 from Behrensmeyer 1978), which indicates a relative short time on the taphonomically active zone (TAZ) with little or no transport.

Another relevant issue is megamammal extinction in South America. Avilla and Winck (2008) propose a metabolic crisis as the main factor acting in the extinction due to temperature increase (decreasing the capacity of energy absorbance in large mammals) and the dominance of low-nutrition grasses. However, the extinction of the mastodon population from Águas de Araxá seems to be related to a catastrophic regional event, probably related to water (e.g., torrential rain for a very long time, and/or flooding, since the area was considered near a paleo-stream). First, there is no patterned selection of age-class or size - all age groups and a complete size range are represented in this fossil assemblage (Fig. 6). Also, we have no clear evidence of a declining period prior to the death event. We exclude hunting by humans because this process would probably have been biased towards subadults or smaller adults (Haynes and Klimowicz 2003). In Clovis mammoth assemblages from North America, the largest assemblage (Lehner, Arizona) shows 61\% subadults mammoths, and in Dent (Colorado) about 83\% (Saunders 1980). In the assemblage studied here, about $23 \%$ mastodons were subadults (Fig. 6D). Although gomphotheres appear to have been a human food resource in Colombia, Venezuela and Chile, there is no record of an association with artifacts or human remains in Argentina (Sánchez et al. 2004) and Brazil (C. Cartelle personal communication 2007). Moreover, a detailed analysis of borings and marks on cranial and postcranial bones of the Águas de Araxá assemblage has not identified any human modifications (Dominato et al. 2009). Therefore, the hypothesis of catastrophic death, as suggested by Simpson and Paula-Couto (1957), seems to be very plausible at this time. However, as the collection site is inaccessible, the acquisition of the taphonomic information necessary to elucidate this question is not possible at present.

Classical demographic theory postulates that poliginical species possess female mortality and reproductive rate as the main influences on the population dynamics (Krebs 1985). Also, some authors suggest a strong density-dependent relationship between female population size and recruitment, compared to total population size (McCullough et al. 1990, Teer 1984 apud Giles and Findlay 2004). To further investigate these features, a study on sex identification is under development. Paleoecological modeling seems to be the most productive way to understand the preponderance of adult individuals in this population, and to reliably assess the population health and status (i.e., increasing or stable population). 


\section{CONCLUSION}

We consider the morphometric index able to define intermediate age groups, since it produced three recognizable intermediate wear stages. This is a testable methodology and a not subjective one, unlike the efforts of Simpson and Paula-Couto (1957). In this paper, we have argued the importance of providing a better characterization of the population status (stable or in recovery) when the assemblage was created by a single moment of death and burial event. It seems likely that this group of animals perished in a catastrophic event and we further suggest that this population disappearance is unrelated to the mass extinction of Pleistocene South American megamammals. The age classes pattern suggests a fossil assemblage composed of aggregated family units placed in a savannah-like vegetation during a period of low humidity and resources scarcity. A possibility to infer the environmental features of the assemblage's locality through modeling demographic status of the population has emerged from this study. Further studies on ecological modeling will be conducted to shed more light on the population status based on analogies with extant elephant ecology.

\section{ACKNOWLEDGMENTS}

The authors wish to thank Rodrigo Rocha Machado (Departamento Nacional de Produção Mineral, Brazil) for accessing the mastodons collection from Águas de Araxá; Admiral Ibsen de Gusmão Câmara for suggestions, contributions and English improvements on the early versions of the manuscript; Victor Hugo Dominato for helping with the pictures; Fundação Carlos Chagas Filho de Amparo à Pesquisa do Estado do Rio de Janeiro (FAPERJ) for the concession of doctoral (GRW; E-26/100.769/2008) and undergraduate (DM; 384 E-26/ $100.134 / 2008)$ grants.

\section{RESUMO}

O registro fossilífero do Quaternário de Águas de Araxá (QAA) é representado principalmente pelo acúmulo de restos dentários e de esqueleto de diversos tamanhos, atribuídos a uma população pretérita do mastodonte Stegomastodon waringi. Foram analisados 97 molares de acordo com os estágios de desgaste propostos por Simpson e Paula-Couto 1957, e desen- volveu-se um índice morfométrico de desgaste. A estrutura populacional (proporção entre indivíduos imaturos, subadultos, adultos, adultos maduros e adultos senis) foi identificada e comparada com populações de elefantes atuais. Foi possível estabelecer que esta população era amplamente composta por adultos: $14,89 \%$ eram indivíduos imaturos; $23,04 \%$ eram subadultos; $27,65 \%$ eram adultos; $17,21 \%$ eram adultos maduros e outros $17,21 \%$ eram adultos senis. Baseados na estrutura populacional observada, não se descartou a possibilidade desta população estar estável ou em recuperação e/ou de ter passado por um período de predação dos indivíduos mais jovens. $\mathrm{O}$ número de indivíduos encontrados nesta população sugere que esta ocupava um ambiente aberto, de acordo com comparações com populações de elefantes atuais. Considerou-se a assembléia de mastodontes do Quaternário de Águas de Araxá como uma agregação de unidades familiares, o que sugere um momento de baixa umidade ambiental. Baseados em literatura e nos resultados encontrados, a sua extinção parece ser regional e possivelmente relacionada a um evento catastrófico.

Palavras-chave: Stegomastodon waringi, classes etárias, índice morfométrico de desgaste, estruturas populacionais.

\section{REFERENCES}

Aguirre E. 1969. Evolutionary History of the Elephant. Science 164(3886): 1366-1376.

Alberdi MT, Prado JL and Cartelle C. 2002. El registro de Stegomastodon (Mammalia, Gomphotheriidae) en el Pleistoceno superior de Brasil. Rev Esp Paleo 17(2): 217-235.

Alberdi Mt, Prado JL, Ortiz-Jaureguizar E, PosaDAS P AND DONATO M. 2007. Historical biogeography of trilophodont gomphotheres (Mammalia, Proboscidea) reconstructed applying dispersion-vicariance analysis. In: DÍAZ-MARTínez E AND RÁBANO I (Eds), $4^{\text {th }}$ European Meeting on the Palaeontology and Stratigraphy of Latin America, Madrid, Cuadernos del Museo Geominero (8): 9-14.

Asher RJ AND Lehmann T. 2008. Dental eruption in afrotherian mammals. BMC Biol 6(14): 1-11.

Avilla LS AND Winck GR. 2008. A extinção da megafauna de mamíferos na América do Sul: uma abordagem integrada. In: LANGER MC, BITTENCOURT J AND Sobral G (Eds), VI Simpósio Brasileiro de Paleontologia de Vertebrados, Boletim Informativo da Sociedade Brasileira de Paleontologia, Edição Especial, Ribeirão Preto, SP, Brasil, p. 35-36. 
BADGLeY C. 1986. Counting individuals in mammalian fossil assemblages from fluvial environments. Palaios 1: 328-338.

BeHrensmeYer AK. 1978. Taphonomic and ecologic information from bone weathering. Paleobiology 4: 150-162.

Dominato VHSF, Mothé D, AVILla LS AND BERTONIMACHADO C. 2009. A ação de insetos em vértebras cervicais de Stegomastodon waringi (Gomphotheriidae: Mammalia) do Pleistoceno de Águas de Araxá, Minas Gerais, Brasil. Rev Bras Paleo 12: 77-82.

FroEHLICH J AND KALB JE. 1995. Internal reconstruction of elephantid molars: applications for functional anatomy and systematics. Paleobiology 21(3): 379-392.

Giles BG AND FindLAY CS. 2004. Effectiveness of a selective harvest system in regulating deer populations in Ontario. J Wildl Manage 68(2): 266-277.

HAYNes G. 1991. Mammoths, Mastodonts and Elephants: Biology, Behavior, and the Fossil Record. Cambridge University Press. Cambridge, 424 p.

Haynes G And Klimowicz J. 2003. Mammoth (Mammuthus spp.) and American Mastodont (Mammut americanum) Bonesites: What Do the Differences Mean? Deinsea 9: 185-204.

HildebrandT T ET AL. 2007. Foetal age determination and development in elephants. Proc R Soc 274: 323-331.

Holz M AND Simões MG. 2002. Elementos fundamentais de Tafonomia. $1^{\text {st }}$ ed., Porto Alegre, RS, Brasil, EDUFRGS, $231 \mathrm{p}$.

JOHNSON OW AND BUSS IO. 1965. Molariform teeth of male African elephants in relation to age, body dimensions and growth. J Mammal 46(3): 373-383.

KreBs CJ. 1985. Ecology: The Experimental Analysis of Distribution and Abundance. $3^{\text {rd }}$ ed., New York: Harper and Row, $800 \mathrm{p}$.

KRUMrey WA AND Buss IO. 1968. Age estimation, growth and relationships between body dimensions of the female African elephant. J Mammal 49: 22-31.

LAURSEN L AND BEKOFF M. 1978. Loxodonta africana. Mamm Sp 92: 1-8.

LAws RM. 1966. Age criteria for the African elephant Loxodonta a. africana. East Afr Wildl J 4: 1-37.

LEDRU MP. 1993. Late Quaternary environmental and climatic changes in central Brazil. Quat Res 39: 90-98.

LEDru MP, Braga PIS, Soubiès F, Fournier M, Martin L, Suguio K And TurCQ B. 1996. The last 50,000 years in the Neotropics (Southern Brazil): evolution of vegetation and climate. Palaeogeog palaeoclim palaeoecol 123: 239-257.
Loveridge AJ, Hunt JE, Murindagomo F And MaCDONALD DW. 2006. Influence of drought on predation of elephant (Loxodonta africana) calves by lions (Panthera leo) in an African wooded savannah. J Zool 270: 523-530.

MAGLio VJ. 1972. Evolution of mastication in the Elephantida. Evolution, 26(4): 638-658.

Marshall F AND Pilgram T. 1993. NISP vs. MNI in quantification of body-part representation. Am Ant 58(2): 261-269.

McCullough DR, Pine DS, Whitmore DL, MansFIELD TM AND DECKER RH. 1990. Linked sex harvest strategy for big game management with a test case on blacktailed deer. Wildl Monogr 112: 1-41.

McNeil P, Hills LV, Kooyman B And Tolman SM. 2004. Mammoth tracks indicate a declining Late Pleistocene population in southwestern Alberta, Canada. Quat Sci Rev 24: 1253-1259.

Moss C. 1996. Getting to know a population. In: KANGWANA K (Ed), Studying Elephants, Kenya: African Wildlife Foundation, p. 58-74.

Mothé D AND Avilla LS. 2008. A Dentição decídua de Stegomastodon waringi (Proboscidea, Gomphotheriidae): Morfologia e padrões de substituição e desgaste. In: LANGer MC, Bittencourt J AND Sobral G (Eds), VI Simpósio Brasileiro de Paleontologia de Vertebrados, Boletim Informativo da Sociedade Brasileira de Paleontologia. Edição Especial, Ribeirão Preto, SP, Brasil, p. 139-140.

OSBORN HJ. 1921. The evolution, phylogeny and classification of the Proboscidea. Ame Mus Nov (1): 1-15.

OWEN-SMITH RN. 2000. Social organization and behavior. In: OWEn-SMith RN (Ed), Megaherbivores: The influence of very large body size on ecology. Cambridge: Cambridge University Press, p. 101-132.

Packer C, Hilborn RH, Mosser A, Kissui B, BorNer M, Hopcraft G, Wilmshurst J, Mduma S AND SINCLAIR SRE. 2005. Ecological change, group territoriality, and population dynamics in Serengeti lions. Science 307: 390-393.

Paula-Couto C. 1979. Tratado de Paleomastozoologia. Rio de Janeiro: Academia Brasileiras de Ciências, p. 445-470.

PERRY JS. 1953. The reproduction of the African elephant, Loxodonta africana: Series B. Biol Sciences 237: 93-149.

Peyer B. 1968. Comparative Odontology. Chicago: The University of Chicago Press, $458 \mathrm{p}$.

Prado JL And Alberdi MT. 2008. A Cladistic Analysis among Trilophodont gomphotheres (Mammalia, Pro- 
boscidea) with special attention to the South American genera. Palaeontology 51(4): 903-915.

Prado JL, Alberdi MT, Azanza B, SÁnchez B ANd Frassinetti D. 2001. The Pleistocene Gomphotheres (Proboscidea) from South America. Quat Int 126-128: 21-30.

Prevosti FJ AND Vizcaíno SF. 2006. Paleoecology of the large carnivore guild from the late Pleistocene of Argentina. Acta Palaeo Pol 51(3): 407-422.

PRICE LI. 1944. O depósito de vertebrados pleistocênicos de Águas de Araxá (Minas Gerais). An Acad Bras Cienc 16(3): 193-195.

Prothero DR AND SCHOCh RM. 2002. Horns, tusks, and flippers: the evolution of hoofed mammals. The Johns Hopkins University Press, Baltimore, p. 157-195.

Roth VL And Shoshani J. 1988. Dental identification and age determination in Elephas maximus. J Zool 214: 567588 .
SÁnchez B, Prado JL And Alberdi MT. 2004. Feeding ecology, dispersal, and extinction of South American Pleistocene gomphotheres (Gomphotheriidae, Proboscidea). Paleobiology 30: 146-161.

SAUNDERS JJ. 1980. Model for man-mammoth relationships in Late Pleistocene North America. Can J Anthropol 1: 87-98.

SHOSHANi J. 1998. Understanding proboscidean evolution: a formidable task. Trends Ecol Evol 13(12): 480-487.

Simpson GG And PAula-Couto C. 1957. The Mastodonts of Brazil. American Museum of Natural History 112(2): 131-145.

VAUghan TA, Ryan JM And CZAPlewski NJ. 2000. Mammalogy. Saunders College Publishing, Orlando, p. 246-250. 